Original Research Article

\title{
Physico-chemical features of water in Betana wetland, Belbari, Morang, Nepal
}

Ganesh Bahadur Thapa ${ }^{1}$ and Joydeb Pal ${ }^{2}$

'Department of Zoology, Central Campus of Technology, Dharan TU, Nepal.

${ }^{2}$ Department of Zoology, University of North Bengal, Darjeeling, West Bengal, India.

*Corresponding Author: Ganesh Bahadur Thapa, Department of Zoology, Central Campus of Technology, Dharan TU, Nepal, E-mail: ganeshbdr13@gmail.com

\begin{abstract}
:
Different physico-chemical parameters in Betana wetland pond water was studied for two years. Air temperature showed positive and significant correlation with water temperature $(\mathrm{r}=0.947, \mathrm{P}<0.01)$ but it had inverse and significant correlation with free $\mathrm{CO}_{2}(\mathrm{r}=-0.685, \mathrm{P}<0.05), \mathrm{pH}(\mathrm{r}=-0.653, \mathrm{P}<0.05)$ and $\mathrm{DO}(\mathrm{r}=-0.582, \mathrm{P}<0.05)$. The water temperature showed positive and significant correlation with phosphate $(\mathrm{r}=0.635, \mathrm{P}<0.05)$ but it showed inverse and significant correlation with $\mathrm{pH}(\mathrm{r}=-0.692, \mathrm{P}<0.05), \mathrm{DO}(\mathrm{r}=-0.576, \mathrm{P}<0.05)$ and free $\mathrm{CO}_{2}(\mathrm{r}=-0.798$, $\mathrm{P}<0.01)$. Free $\mathrm{CO}_{2}$ showed inverse and significant correlation with chloride $(\mathrm{r}=-0.596, \mathrm{P}<0.05)$. BOD showed no significant positive correlation but it had inverse and significant correlation with $\mathrm{pH}(\mathrm{r}=-0.613, \mathrm{P}<0.05)$. Total acidity (TA) showed positive and significant correlation with total hardness $(\mathrm{TH})(\mathrm{r}=0.580, \mathrm{P}<0.05)$ but inverse and significant correlation with water temperature $(\mathrm{r}=-0.623, \mathrm{P}<0.05)$ and phosphate $(\mathrm{r}=-0.608, \mathrm{P}<0.05)$. All physico -chemical parameters of Betana pond water were within permissible range for wild fish and fish culture. Outbreak of any fish diseases did not occur during Nov.2008-Oct. 2010. Being ecotourism area, maintenance of water quality should be done by periodic evaluation of physico-chemical parameters of the pond water.
\end{abstract}

Key words: Physico-chemical, variations, Seasons, correlation, Betana wetlands, Nepal

\section{Introduction}

Betana wetland consists of an ox-bow lake with an area of 5.5 ha and often flooded during rainy season. It is surrounded by sal forests (Charkoshe Jhaadi) in east, north and west sides and Mahendra highway in the south near Belbari, Morang, Nepal. Now it is being developed as ecotourism area. It has rich biodiversity and provides more research ground but deteriorations of quality of water and species diversity will be faced due to anthropogenic activities. So, periodic evaluation of water quality and maintenance is necessary in Betana wetland.

Several earlier workers who had studied in the field of limnology were: Swarup and Singh (1979); Das (1981); Bhowmick and Singh (1985); Wright et al, (1985); Lohman et al, (1988); Gautam (1990); Jhingran (1991); Bose and Gorai (1993); Jindal and Kumar (1993); Patralekh (1994); Gupta and Shrivastava (1994); McEachern (1994) ;Singh (1995); Pandey and Lal (1995); Rawat et al, (1995); Ormerod et al, (1996); Aryal and Lacoul (1996) and Sharma and Agarwal (1999) Likewise, Latifa and Acharya (2001) in Bangladesh, Barat and Jha (2002) in North Bengal, Palui et al, (2003) in North Bihar, Sakhare and Joshi (2004) in Maharastra, Samal and Majumdar (2005) in Rabindra and Subashsarobar India, Yousuf et al, (2006) in Kashmir, Singh et al, (2008), Acharjee and Barat(2011) in Relli river of Darjeeling and Mary Helen et al, (2011) in Tamil Nadu were some of the other workers in limnology.

Sharma (1996) studied limnology of Koshi River in North Bihar, Jana (1998) summarized the limnological data for about 60 lakes and reservoirs of India. Jain et al, (1999) reported positive correlation between $\mathrm{pH}$ and DO and water temperature with $\mathrm{pH}$ but negative correlation with free $\mathrm{CO}_{2}$ and alkalinity of a sacred lake Khecheopalri of Sikkim. Mishra et al, (1999) worked on limnology of a freshwater tributary and reported maximum DO, TA and chloride in winter season and free $\mathrm{CO}_{2}$ in monsoon season. Onada et al, (2015) found that the values of DO and temperatures showed significant variations between the times of the day in Nazarene Fish Farm, Ibadan, Nigeria. Parisara (2015) studied the physico-chemical parameters and its correlation of Konandur pond in Thirthalli, Karnataka, India and 
showed that mostly positive correlation so the water quality was not much polluted.

In Nepal, Niroula et al, (2010) revealed $\mathrm{pH}$, conductivity, turbidity, total phosphorus and TA were higher in summer whereas TDS, $\mathrm{NO}_{3}^{-}, \mathrm{TH}\left(\mathrm{CaCO}_{3}\right), \mathrm{DO}, \mathrm{BOD}$ and $\mathrm{Cl}^{-}$ content were higher in winter and water temperature, ammonia and carbon dioxide were higher in rainy season. More seasonal fluctuations in turbidity, carbon dioxide and chloride content were observed in Betana pond, Belbari Morang. The physico-chemical parameters of Koshi River were studied at the Kushaha area, Nepal (ThapaChhetry and Pal, 2011). Ambient and surface water temperature showed a significant correlation with free carbon dioxide and BOD and an inverse and significant correlation with $\mathrm{pH}, \mathrm{DO}$, total alkalinity, total hardness and chloride. Thapa and Pal (2012) studied the water quality of Baidya fish pond and was normal except high fluctuation of chloride $(1 \pm 0.241$ to $29.84 \pm 0.260$ $\mathrm{mg} / \mathrm{L}$ and ammonia $1.55 \pm 0.088$ to $18.7 \pm 0.061 \mathrm{mg} / \mathrm{L}$ ) during manuaring period. Mondal et al, (2012) reported the physico-chemical status of surface water of Mirik Lake in Darjeeling from seven locations. Thapa and Pal (2014) studied physico-chemical parameters of Singhia and Budhi rivers in Sunsari and Morang industrial corridor, Nepal.

Detailed study of physico-chemical features of water of Betana wetland has not been carried out so far; present study is relevant to reveal the properties of water up to some extent for the maintenance of its ecological condition.

\section{Methodology}

Site: The site chosen for this study was Betana Wetland, Belbari, Morang (Fig. a and b) which is located at latitude $26^{\circ} 39^{\prime} 37.79^{\prime \prime} \mathrm{N}$ and Longitude $87^{\circ} 25^{\prime} 55.50^{\prime \prime} \mathrm{E}$.

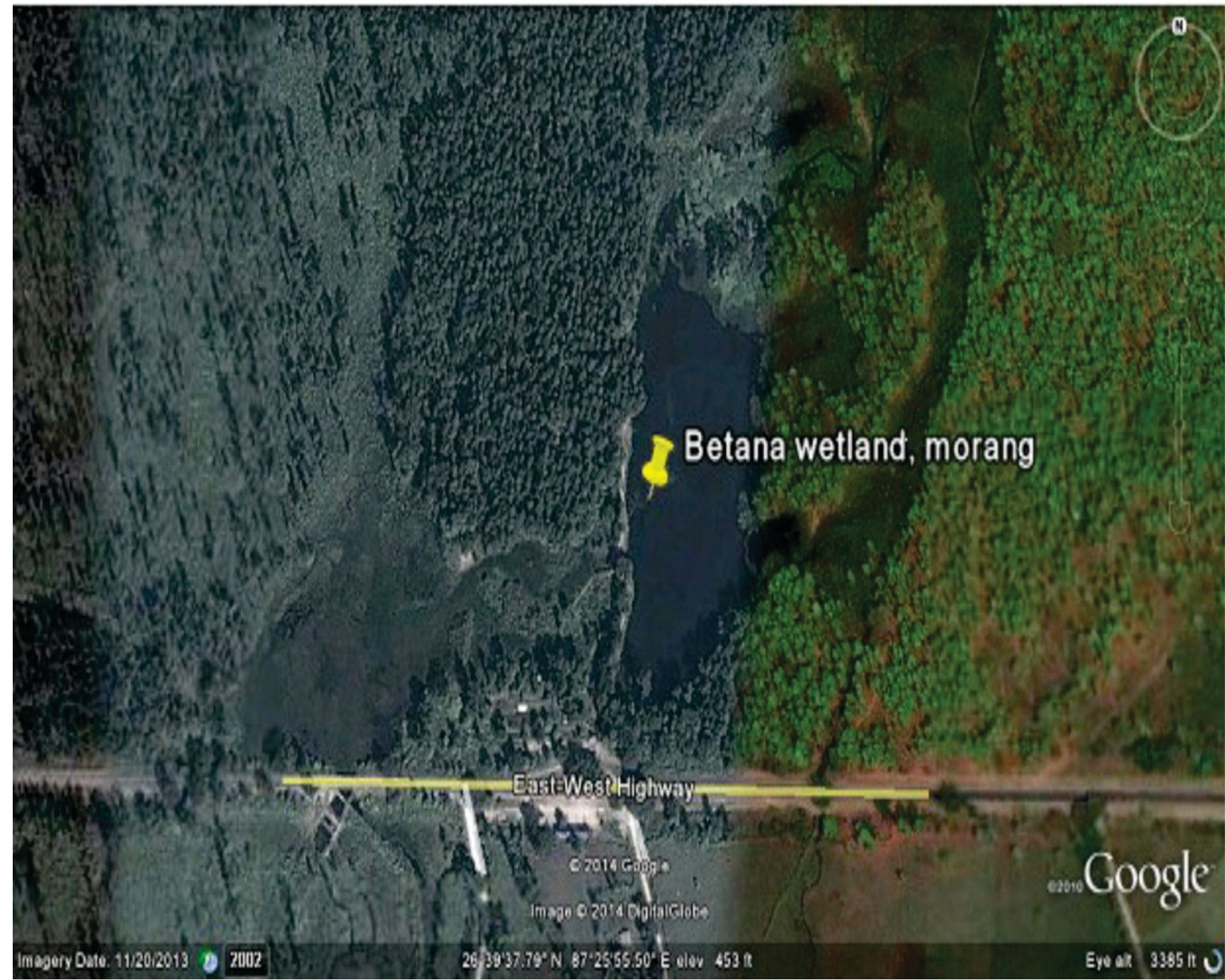




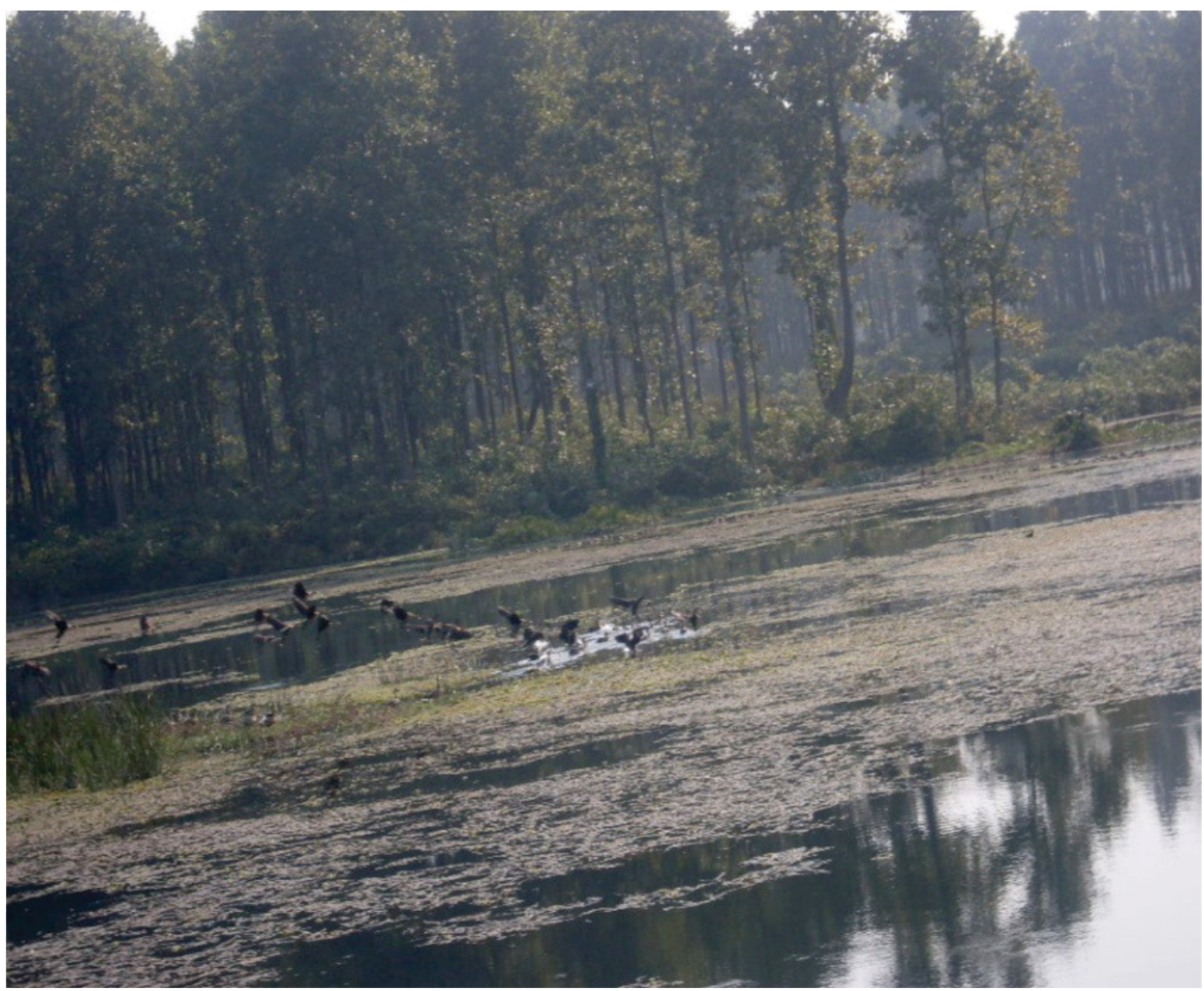

Fig 1. Betana wetland, Belbari, Morang

\section{Physico-chemical parameters of water samples}

Sample was collected between 8.00-11.00 A.M. on $15^{\text {th }}$ day of each month during two years (Nov.2008Oct.2010) in an ice box. Temperature was recorded on the site by glass thermometer. The $\mathrm{pH}$ of water was determined on the site by Hanna's pocket $\mathrm{pH}$ meter. All other physico-chemical analysis of water like Dissolved Oxygen (DO), Biological oxygen demand (BOD), free carbon dioxide (free $\mathrm{CO}_{2}$ ), chloride ions $\left(\mathrm{Cl}^{-}\right)$, total alkalinity (TA), total hardness (TH) and phosphate were determined following standard methods (Trivedy and Goel, 1986; APHA, 2005). Obtain values were compared with standard values from the Betana pond.

\section{Statistical Analysis}

Standard deviation, Mean, correlation coefficient were calculated by using Microsoft excel statistical function of computer software. The significance of correlation coefficient was tested by applying t-test by using SPSSV20 computer software.

\section{Results and Discussion}

Results of the air temperature and physico-chemical parameters of pond water of Betana wetland are shown in Tables 1 and 2. Table 1 shows the results of air temperature and physico-chemical parameters of water of the first year (Nov.2008 - Oct.2009) study period.
Table 2 shows the results of air temperature and physicochemical parameters of water of the second year (Nov. 2009- Oct. 2010). Table 3 shows the correlation coefficient (r) of air temperature and different physicochemical parameters of water at the site. 


\section{Air temperature}

The minimum air temperature was $18.03 \pm 0.347{ }^{\circ} \mathrm{C}$ in December and maximum was $31.01 \pm 0.274^{\circ} \mathrm{C}$ in August during the Nov.2008-Oct.2009 (Table 1). The maximum air temperature was $29.1 \pm 0.285^{\circ} \mathrm{C}$ in the month of March and minimum $17.10 \pm 0.237^{\circ} \mathrm{C}$ in the month of January during the Nov. 2009- Oct.2010 (Table 2). Air temperature showed positive and significant correlation with water temperature $(\mathrm{r}=0.947, \mathrm{P}<0.01)$ but it had inverse and significant correlation with free $\mathrm{CO}_{2}(\mathrm{r}=$ $0.685, \mathrm{P}<0.05), \mathrm{pH}(\mathrm{r}=-0.653, \mathrm{P}<0.05)$ and $\mathrm{DO}(\mathrm{r}=$ $0.582, \mathrm{P}<0.05)$ (Table 3$)$.

During first year (Nov.2008 - Oct.2009), the air temperature showed declining trend in the month of November. In the month of December 2008, it was lowest $\left(18.03 \pm 0.347{ }^{\circ} \mathrm{C}\right)$ and it increased slightly $(18.10$ $\pm 0.523)$ in the month of January, 2009. Thereafter it increased February onwards up to March (Table 1).The air temperature during the second (Nov. 2009- Oct.2010) year showed decreasing trends from November to January and during the months of August to October in both years (Tables 1,2). The results of the study on water parameters clearly showed that different physicochemical factors of the Betana wetland varied during the two years study period. The highest air temperature was recorded in the month of March and August in S4. It was mainly due to geographical positions and weather conditions. The minimum air temperature was recorded in the month of December and January in the site. Air temperature showed positive and significant correlation with water temperature at the site (Table 3). Rawat et al, (1995) also obtained strong positive significant correlation between air and water temperatures.

\section{Water temperature}

The maximum water temperature was $29.12 \pm 0.235^{\circ} \mathrm{C}$ in August and minimum $17.14 \pm 0.316^{\circ} \mathrm{C}$ in the month of January during the first year (Nov.2008-Oct.2009) (Table 1). During the second year (Nov. 2009-Oct.2010) study period, the maximum water temperature was 28.12 $\pm 0.523^{\circ} \mathrm{C}$ in August and minimum $18.04 \pm 0.365{ }^{\circ} \mathrm{C}$ in the January (Table 2). The water temperature showed positive and significant correlation with air temperature $(\mathrm{r}=0.947, \mathrm{P}<0.01) \mathrm{P}<0.01)$ and phosphate $(\mathrm{r}=0.635$, $\mathrm{P}<0.05)$ but it showed inverse and significant correlation with $\mathrm{pH}(\mathrm{r}=-0.692, \mathrm{P}<0.05), \mathrm{DO}(\mathrm{r}=-0.576, \mathrm{P}<0.05)$ and free $\mathrm{CO}_{2}(\mathrm{r}=-0.798, \mathrm{P}<0.01)$ (Table 3$)$.

The water temperature showed decreasing trend during the winter months from November to January and also in August to October in both years (Tables 1,2). Water temperature is influenced by air temperature and intensity of solar radiation. It showed positive and significant correlation with free $\mathrm{CO}_{2}$ and BOD at this site but had inverse and significant correlation with $\mathrm{pH}, \mathrm{DO}, \mathrm{TA}$ and TH. Bose and Gorai (1993) reported negative significant correlation between water temperature and DO.

\section{pH}

The maximum $\mathrm{pH}$ was $8.15 \pm 0.365$ in the month of January and minimum $6.64 \pm 0.271$ in September during the first year (Nov.2008 - Oct.2009) study period (Table 1). The maximum $\mathrm{pH}$ was $7.60 \pm 0.327$ in December and minimum was $6.61 \pm 0.229$ in February during second year (Nov.2009 - Oct.2010) (Table 2). pH showed inverse and significant correlation with air temperature $(\mathrm{r}=-0.653, \mathrm{P}<0.05)$, water temperature $(\mathrm{r}=-0.692, \mathrm{P}<$ $0.05)$ and $\mathrm{BOD}(\mathrm{r}=-0.613, \mathrm{P}<0.05)($ Table 3$)$.

$\mathrm{pH}$ of the study site varied in different seasons. The maximum $\mathrm{pH}$ in winter season may be attributed to algal blooms as shown by Hutchinson et al, (1992) and Roy (1955). Several workers have reported low $\mathrm{pH}$ during the low photosynthesis due to the formation of carbonic acid (Bais et al, 1995). But Gautam (1990) reported highest $\mathrm{pH}$ in summer and lowest in rainy season. The $\mathrm{pH}$ showed positive and significant correlation with $\mathrm{DO}$ at the site. It was inverse and significantly correlated with air temperature and water temperature at the site (Table 3). Rawat et al, (1995) reported positive correlation with TA and inverse correlation with water temperature.

\section{Free carbon dioxide}

The maximum free $\mathrm{CO}_{2}$ was recorded to be $73.92 \pm 1.552$ $\mathrm{mg} / \mathrm{L}$ in September and minimum $3.37 \pm 0.638 \mathrm{mg} / \mathrm{L}$ in May during the first year (Nov.2008 - Oct.2009) study period (Table 1). The maximum free $\mathrm{CO}_{2}$ was $23.75 \pm$ $0.874 \mathrm{mg} / \mathrm{L}$ in January and minimum $2.24 \pm 0.557 \mathrm{mg} / \mathrm{L}$ in April during the second year (Nov.2009 - Oct.2010) (Table 2). Free $\mathrm{CO}_{2}$ showed inverse and significant correlation with chloride $(\mathrm{r}=-0.596, \mathrm{P}<0.05)$, water temperature $(\mathrm{r}=-0.798, \mathrm{P}<0.01)$, air temperature $(\mathrm{r}=$ $0.685, \mathrm{P}<0.05)($ Table 3$)$.

The maximum free $\mathrm{CO}_{2}$ was recorded in summer, it may be due to high temperature, high rate of decomposition of organic matter, low volume of water etc. Michael (1969) stated that the concentration of $\mathrm{CO}_{2}$ is directly correlated with the amount and nature of biological activity in water. Pahwa and Mehrotra (1966), Ray et al, (1966), Gautam (1990), and Pandey and Lal (1995) also found minimum free $\mathrm{CO}_{2}$ in winter. Free $\mathrm{CO}_{2}$ of water showed positive and significant correlation with water temperature and $\mathrm{BOD}$ and inverse and significant correlation with DO (Table 3). Pahwa and Mehrotra (1966) observed inverse correlation of free $\mathrm{CO}_{2}$ with $\mathrm{DO}$. 


\section{Dissolved Oxygen}

The maximum DO was $7.31 \pm 0.185 \mathrm{mg} / \mathrm{L}$ in January and minimum $3.19 \pm 0.379 \mathrm{mg} / \mathrm{L}$ in August during the first year (Nov.2008 - Oct.2009) study period (Table 1). The maximum DO was $9.74 \pm 0.235 \mathrm{mg} / \mathrm{L}$ in April and minimum $3.19 \pm 0.254 \mathrm{mg} / \mathrm{L}$ in June (Table 2). The DO showed inverse and significant correlation with water temperature $(\mathrm{r}=-0.596, \mathrm{P}<0.05)$ and air temperature $(\mathrm{r}=$ $0.582, \mathrm{P}<0.05)$ (Table 3$)$.

The maximum DO was recorded in winter season followed by rainy and summer seasons at the site. The maximum DO found in winter season may be due to low temperature as shown by Moitra and Bhattacharya (1965). The minimum DO was found in summer due to high temperature and higher microbial demand for oxygen in decomposition of suspended organic matter (Bhowmick and Singh, 1985; Palharya and Malvia, 1988). Elmore and West (1961) stated that an increase in temperature of water resulted in the decrease of DO content of water. DO content showed positive and significant correlation with TA and TH. It was positively correlated with chloride at the site. It showed inverse and significant correlation with water temperature, free $\mathrm{CO}_{2}$ and BOD. Bose and Gorai; Jindal and Kumar (1993) also reported inverse and significant correlation of DO with water temperature.

\section{Biological Oxygen Demand}

The maximum BOD was $4.62 \pm 0.254 \mathrm{mg} / \mathrm{L}$ in the month of September and minimum was $0.84 \pm 0.014 \mathrm{mg} / \mathrm{L}$ in the month of February during the first year (Nov.2008 Oct.2009) study period (Table 1). During the second year (Nov.2009 - Oct.2010), the maximum BOD $6.22 \pm 0.048$ $\mathrm{mg} / \mathrm{L}$ was seen in the month of April and minimum $0.26 \pm$ $0.076 \mathrm{mg} / \mathrm{L}$ in the month of December (Table 2). BOD showed no significant positive correlation but it had inverse and significant correlation with $\mathrm{pH}(\mathrm{r}=-0.613$, $\mathrm{P}<0.05$ ) (Table 3). The BOD of water of the study site varied between $0.26 \pm 0.076 \mathrm{mg} / \mathrm{L}$ and $6.22 \pm 0.048 \mathrm{mg} / \mathrm{L}$ during the study period. The maximum BOD obtained in summer may be due to low volume of water and high content of organic matter whereas minimum obtained in winter may be due to low temperature and retarded microbial activity for the decomposition of organic matters. Similar observations were also made by Singh (1995). Ray and David (1966) opined that high BOD value indicates organic waste pollution. BOD showed positive and significant correlation with air temperature, water temperature and free $\mathrm{CO}_{2}$ and inverse and significant correlation with $\mathrm{pH}$ and DO (Table 3). Ray and David (1966), and Barat and Jha (2002) also reported inverse correlation of BOD with DO.

\section{Chloride}

The maximum chloride was $5.02 \pm 0.531 \mathrm{mg} / \mathrm{L}$ in June and minimum was $2.02 \pm 0.095 \mathrm{mg} / \mathrm{L}$ in September during the first year (Nov.2008 - Oct.2009) study period (Table 1). During the second year(Nov.2009-Oct.2010), the maximum chloride was $7.05 \pm 0.324 \mathrm{mg} / \mathrm{L}$ in January and minimum $1.01 \pm 0.093 \mathrm{mg} / \mathrm{L}$ in March (Table 2). Chloride showed inverse and significant correlation with free $\mathrm{CO}_{2}(\mathrm{r}=-0.596, \mathrm{P}<0.05)$ (Table 3).

The minimum chloride was recorded in March of the second year(Nov.2009 - Oct.2010) at the site (Table 2). The maximum quantity of chloride recorded at Betana pond in summer season may be due to low volume of water, high temperature and high rate of decomposition of organic matters. Chloride concentration indicates the presence of organic waste of animal origin (Thresh et al, 1949). Ganapati (1941, 1943), and Swarup and Singh (1979) also reported an increase in chloride during summer. Minimum quantity of chloride recorded in rainy season might be due to dilution by rain water. Klein (1957) pointed out a direct relationship between amount of chloride and level of pollution. Chloride showed positive and significant correlation with total alkalinity.

\section{Total alkalinity}

The maximum TA was recorded $195.33 \pm 1.776 \mathrm{mg} / \mathrm{L}$ in February and minimum $69.56 \pm 1.152 \mathrm{mg} / \mathrm{L}$ in December during the first year (Nov.2008 - Oct.2009) study period (Table 1). During the second year (Nov. 2009-Oct. 2010), the maximum TA recorded was $197.43 \pm 2.756 \mathrm{mg} / \mathrm{L}$ in February and minimum was $103.23 \pm 0.867 \mathrm{mg} / \mathrm{L}$ in September (Table 2). The TA showed positive and significant correlation with $\mathrm{TH}(\mathrm{r}=0.580, \mathrm{P}<0.05)$ (Table $3)$. TA remained low during August, September and October in the first year study period. TA in the month of June $(116.62 \pm 0.956 \mathrm{mg} / \mathrm{L})$ significantly $(\mathrm{p}<0.01)$ decreased in comparison to that of May $(132.01 \pm 1.742$ $\mathrm{mg} / \mathrm{L}$ ) in the first year (Table 1). There were fluctuations in the values of TA during March, April, May and June, 2009. Similar patterns in TA were noticed during second year study period (Table 2 ).

The TA was found maximum in the month of January/February at the site. It was found maximum in winter season due to high pH Singh (1990) and Mishra et al, (1998) also reported maximum TA during winter. Water bodies having TA from 40 to $90 \mathrm{mg} / \mathrm{L}$ is considered as medium productive and above $90 \mathrm{mg} / \mathrm{L}$ as highly productive (Jhingran, 1991). This investigation showed that the study area is suitable for aquatic production. TA showed positive and significant correlation with $\mathrm{TH}$ and chloride. Barat and Jha (2002) also reported positive and 
significant correlation of $\mathrm{TH}$ with hardness. There was significant $(\mathrm{p}<0.01)$ differences in values of TA of water bodies between months but insignificantly $(p>0.05)$ different among corresponding months between first and second years (Table 3 ).

\section{Total hardness}

The maximum hardness was $130.43 \pm 1.623 \mathrm{mg} / \mathrm{L}$ in February and minimum $97.02 \pm 0.754 \mathrm{mg} / \mathrm{L}$ in August during the first year (Nov.2008 - Oct.2009) study period (Table 1). During the second year (Nov.2009-Oct.2010), the maximum $\mathrm{TH}$ was $118.84 \pm 1.623 \mathrm{mg} / \mathrm{L}$ in February and minimum was $89.13 \pm 0.659 \mathrm{mg} / \mathrm{L}$ in September (Table 2). TH showed positive and significant correlation with TA $(r=0.580, P<0.05)$ but inverse and significant correlation with water temperature $(\mathrm{r}=-0.623, \mathrm{P}<0.05)$ and phosphate $(\mathrm{r}=-0.608, \mathrm{P}<0.05)$ (Table 3$)$. The values of TH in March (108.91 $\pm 0.745 \mathrm{mg} / \mathrm{L})$ showed significant decrease $(\mathrm{p}<0.01)$ as compared to February $(130.43$ $\pm 1.623 \mathrm{mg} / \mathrm{L})$ in the first year. It remained low for six months from March to August (Table 1). In 2010, it showed a decreasing trend from March to September for

Table 1. Temperature, water temperature and physico-chemical parameters of water at Betana wetland pond, Belbari, Morang from November 2008- October 2009 (Mean \pm S.D., N=5).

\begin{tabular}{|c|c|c|c|c|c|c|c|c|c|c|c|c|}
\hline \multirow{2}{*}{$\begin{array}{l}\text { Parame } \\
\text { ters } \\
\text { Site - I } \\
\text { Yr. }\end{array}$} & \multicolumn{12}{|c|}{ Months } \\
\hline & Nov & Dec & Jan & Feb & Mar & Apr & May & Jun & Jul & Aug & Sep & Oct \\
\hline $\begin{array}{l}\text { Air } \\
\text { Temp. } \\
{ }^{\circ} \mathrm{C}\end{array}$ & $\begin{array}{l}21.18 \\
\pm 0.259\end{array}$ & $\begin{array}{l}18.03 \\
\pm 0.34 \\
7\end{array}$ & $\begin{array}{r}18.10 \\
\pm .523\end{array}$ & $\begin{array}{l}24.85 \\
\pm 0.36 \\
9\end{array}$ & \begin{tabular}{|l|}
29.99 \\
\pm 0.62 \\
8
\end{tabular} & $\begin{array}{l}27.78 \\
\pm 0.77 \\
5\end{array}$ & $\begin{array}{l}27.12 \\
\pm 0.32 \\
2\end{array}$ & $\begin{array}{l}26.05 \\
\pm 0.73 \\
1\end{array}$ & $\begin{array}{l}29.86 \\
\pm 0.65 \\
7\end{array}$ & \begin{tabular}{|l}
31.01 \\
\pm 0.2 \\
74
\end{tabular} & $\begin{array}{l}29.15 \\
\pm 0.36 \\
2\end{array}$ & $\begin{array}{l}26.03 \\
\pm 0.55 \\
7\end{array}$ \\
\hline $\begin{array}{l}\text { Water } \\
\text { Temp. } \\
{ }^{\circ} \mathbf{C}\end{array}$ & $\begin{array}{l}19.0 \\
\pm 0.125\end{array}$ & $\begin{array}{l}19.01 \\
\pm 0.21 \\
7\end{array}$ & $\begin{array}{l}17.14 \\
\pm 0.31 \\
6\end{array}$ & $\begin{array}{l}22.12 \\
\pm 0.33 \\
5\end{array}$ & $\begin{array}{l}27.06 \\
\pm 0.52 \\
3\end{array}$ & $\begin{array}{l}27.85 \\
\pm 0.47 \\
5\end{array}$ & $\begin{array}{l}26.07 \\
\pm 0.35 \\
1\end{array}$ & $\begin{array}{l}27.13 \\
\pm 0.32 \\
8\end{array}$ & $\begin{array}{l}28.95 \\
\pm 0.27 \\
2\end{array}$ & $\begin{array}{l}29.12 \\
\pm 0.2 \\
35\end{array}$ & \begin{tabular}{|l}
27.3 \\
\pm 0.53 \\
4
\end{tabular} & $\begin{array}{l}25.07 \\
\pm 0.47 \\
6\end{array}$ \\
\hline pH & \begin{tabular}{|l}
7.82 \\
\pm 0.534
\end{tabular} & $\begin{array}{l}7.66 \\
\pm 0.32 \\
7\end{array}$ & $\begin{array}{l}8.15 \\
\pm 0.36 \\
5\end{array}$ & $\begin{array}{l}7.13 \\
\pm 0.22 \\
9\end{array}$ & $\begin{array}{l}7.61 \\
\pm 0.57 \\
6\end{array}$ & $\begin{array}{l}6.83 \\
\pm 0.31 \\
7\end{array}$ & $\begin{array}{l}7.51 \\
\pm 0.73 \\
3\end{array}$ & $\begin{array}{l}7.34 \\
\pm 0.25 \\
6\end{array}$ & $\begin{array}{l}7.5 \\
\pm 0.07 \\
5\end{array}$ & \begin{tabular}{|l|}
6.93 \\
\pm 0.1 \\
74
\end{tabular} & $\begin{array}{l}6.64 \\
\pm 0.27 \\
1\end{array}$ & \begin{tabular}{|l}
7.31 \\
\pm 0.07 \\
3
\end{tabular} \\
\hline $\begin{array}{l}\text { Free } \\
\mathrm{CO2} \\
(\mathrm{mg} / \mathrm{L})\end{array}$ & $\begin{array}{l}41.36 \\
\pm 1.476\end{array}$ & $\begin{array}{l}37.42 \\
\pm 1.23 \\
5\end{array}$ & $\begin{array}{l}12.15 \\
\pm 0.67 \\
5\end{array}$ & $\begin{array}{l}24.96 \\
\pm 0.88 \\
7\end{array}$ & $\begin{array}{l}6.23 \\
\pm 0.35 \\
3\end{array}$ & $\begin{array}{l}4.58 \\
\pm 0.56 \\
7\end{array}$ & $\begin{array}{l}3.37 \\
\pm 0.63 \\
8\end{array}$ & $\begin{array}{l}5.09 \\
\pm 0.05 \\
6\end{array}$ & $\begin{array}{l}8.03 \\
\pm 0.92 \\
6\end{array}$ & $\begin{array}{l}12.54 \\
\pm 1.3 \\
23\end{array}$ & $\begin{array}{l}73.92 \\
\pm 1.55 \\
2\end{array}$ & \begin{tabular}{|l|}
55.44 \\
8 \\
\pm 0.82 \\
6 \\
\end{tabular} \\
\hline $\begin{array}{l}\text { DO ( } \\
\text { mg/L) }\end{array}$ & \begin{tabular}{|l}
7.08 \\
\pm 0.356
\end{tabular} & \begin{tabular}{|l|}
5.84 \\
\pm 0.06 \\
7
\end{tabular} & $\begin{array}{l}7.31 \\
\pm 0.18 \\
5\end{array}$ & \begin{tabular}{|l}
5.89 \\
\pm 0.12 \\
4
\end{tabular} & \begin{tabular}{|l|}
5.14 \\
\pm 0.06 \\
8
\end{tabular} & $\begin{array}{l}6.88 \\
\pm 0.23 \\
5\end{array}$ & $\begin{array}{l}7.17 \\
\pm 0.34 \\
2\end{array}$ & $\begin{array}{l}4.92 \\
\pm 0.25 \\
4\end{array}$ & \begin{tabular}{|l}
4.82 \\
\pm 0.47 \\
3
\end{tabular} & \begin{tabular}{|l|}
3.19 \\
\pm 0.3 \\
79
\end{tabular} & $\begin{array}{l}5.41 \\
\pm 0.36 \\
2\end{array}$ & \begin{tabular}{|l}
7.16 \\
\pm 0.23 \\
1
\end{tabular} \\
\hline $\begin{array}{l}\text { BOD } \\
(\mathrm{mg} / \mathrm{L})\end{array}$ & $\begin{array}{l}2.61 \\
\pm 0.045\end{array}$ & \begin{tabular}{|l|}
2.25 \\
\pm 0.02 \\
6
\end{tabular} & $\begin{array}{l}1.35 \\
\pm 0.02 \\
9\end{array}$ & \begin{tabular}{|l|}
0.84 \\
\pm 0.01 \\
4
\end{tabular} & $\begin{array}{l}1.22 \\
\pm 0.05 \\
6\end{array}$ & $\begin{array}{l}4.32 \\
\pm 0.06 \\
7\end{array}$ & $\begin{array}{l}3.55 \\
\pm 0.11 \\
5\end{array}$ & $\begin{array}{l}2.81 \\
\pm 0.14 \\
9\end{array}$ & $\begin{array}{l}1.83 \\
\pm 0.05 \\
7\end{array}$ & $\begin{array}{l}1.02 \\
\pm 0.0 \\
65\end{array}$ & $\begin{array}{l}4.62 \\
\pm 0.25 \\
4\end{array}$ & \begin{tabular}{|l|}
2.11 \\
\pm 0.05 \\
6
\end{tabular} \\
\hline $\begin{array}{l}\text { Chlorid } \\
\text { e } \\
(\mathrm{mg} / \mathrm{L})\end{array}$ & $\begin{array}{l}4.10 \\
\pm 0.063\end{array}$ & \begin{tabular}{|l|}
2.03 \\
\pm 0.05 \\
9
\end{tabular} & $\begin{array}{l}4.5 \\
\pm 0.22 \\
6\end{array}$ & \begin{tabular}{|l}
3.61 \\
\pm 0.34 \\
2
\end{tabular} & \begin{tabular}{|l}
3.01 \\
\pm 0.19 \\
2
\end{tabular} & $\begin{array}{l}4.0 \\
\pm 0.23 \\
7\end{array}$ & $\begin{array}{l}4.01 \\
\pm 0.13 \\
5\end{array}$ & $\begin{array}{l}5.02 \\
\pm 0.53 \\
1\end{array}$ & $\begin{array}{l}5.01 \\
\pm 0.10 \\
9\end{array}$ & \begin{tabular}{|l|}
4.03 \\
\pm 0.2 \\
75
\end{tabular} & \begin{tabular}{|l}
2.02 \\
\pm 0.09 \\
5
\end{tabular} & \begin{tabular}{|l|}
3.84 \\
\pm 0.08 \\
2
\end{tabular} \\
\hline $\begin{array}{l}\text { Total } \\
\text { Alkalin. } \\
(\mathrm{mg} / \mathrm{L})\end{array}$ & $\begin{array}{l}115.64 \\
\pm 1.253\end{array}$ & $\begin{array}{l}69.56 \\
\pm 1.15 \\
2\end{array}$ & $\begin{array}{l}122.0 \\
5 \\
\pm 2.63 \\
4\end{array}$ & \begin{tabular}{|l}
195.3 \\
3 \\
\pm 1.77 \\
6
\end{tabular} & $\begin{array}{l}132.0 \\
3 \\
\pm 1.18 \\
7\end{array}$ & $\begin{array}{l}117.2 \\
1 \\
\pm 1.95 \\
3\end{array}$ & $\begin{array}{l}132.0 \\
1 \\
\pm 1.74 \\
2\end{array}$ & $\begin{array}{l}116.6 \\
2 \\
\pm 0.95 \\
6^{* *}\end{array}$ & $\begin{array}{l}130.0 \\
2 \\
\pm 0.98 \\
7\end{array}$ & $\begin{array}{l}118.8 \\
3 \\
\pm 1.7 \\
45\end{array}$ & $\begin{array}{l}109.2 \\
7 \\
\pm 0.85 \\
7\end{array}$ & $\begin{array}{l}119.7 \\
3 \\
\pm 0.99 \\
5\end{array}$ \\
\hline $\begin{array}{l}\text { Total } \\
\text { Hard } \\
\text { (mg/L) }\end{array}$ & $\begin{array}{l}116.28 \\
\pm 2.227\end{array}$ & $\begin{array}{l}112.2 \\
\pm 1.52 \\
3\end{array}$ & $\begin{array}{l}110.0 \\
3 \\
\pm 1.37 \\
8\end{array}$ & \begin{tabular}{|l}
130.4 \\
3 \\
\pm 1.62 \\
3 \\
\end{tabular} & $\begin{array}{l}108.9 \\
1 \\
\pm 0.74 \\
5^{* *}\end{array}$ & $\begin{array}{l}106.9 \\
2 \\
\pm 1.54 \\
4\end{array}$ & $\begin{array}{l}110.8 \\
2 \\
\pm 1.56 \\
3\end{array}$ & $\begin{array}{l}108.9 \\
0 \\
\pm 0.97 \\
6\end{array}$ & $\begin{array}{l}104.9 \\
4 \\
\pm 1.06 \\
5\end{array}$ & $\begin{array}{l}97.02 \\
\pm 0.7 \\
54\end{array}$ & $\begin{array}{l}112.3 \\
2 \\
\pm 0.95 \\
7\end{array}$ & \begin{tabular}{|l|}
110.1 \\
6 \\
\pm 0.81 \\
$7 *$ \\
\end{tabular} \\
\hline $\begin{array}{l}\text { Phosph } \\
\text { ate } \\
\text { (mg/L) }\end{array}$ & $\begin{array}{l}0.03 \\
\pm 0.005\end{array}$ & \begin{tabular}{|l|}
0.06 \\
\pm 0.00 \\
2 \\
\end{tabular} & $\begin{array}{l}0.080 \\
\pm 0.00 \\
3\end{array}$ & \begin{tabular}{|l|}
0.09 \\
\pm 0.00 \\
1 \\
\end{tabular} & \begin{tabular}{|l|}
0.38 \\
\pm 0.00 \\
7
\end{tabular} & $\begin{array}{l}0.75 \\
\pm 0.01 \\
5 \\
\end{array}$ & \begin{tabular}{|l|}
0.58 \\
\pm 0.00 \\
2 \\
\end{tabular} & $\begin{array}{l}0.84 \\
\pm 0.01 \\
3 \\
\end{array}$ & \begin{tabular}{|l}
0.16 \\
\pm 0.00 \\
9 \\
\end{tabular} & \begin{tabular}{|l}
1.23 \\
\pm 0.0 \\
28 \\
\end{tabular} & \begin{tabular}{|l|}
0.25 \\
\pm 0.00 \\
3 \\
\end{tabular} & \begin{tabular}{|l|}
0.01 \\
\pm 0.00 \\
1
\end{tabular} \\
\hline
\end{tabular}

* Significant differences at $1 \%$ level, ** Significant differences at 5\% level. 
seven months with slight fluctuation. The value in May $(106.92 \pm 1.563 \mathrm{mg} / \mathrm{L})$ was significantly decreased $(\mathrm{P}<0.05)$ as compared to April $(110.78 \pm 1.544 \mathrm{mg} / \mathrm{L})$ in the second year (Table 2). It remained low for six months from May to October in the second year.

The maximum TH in winter season might be due to low volume and slow current of water. Similar results were obtained by Mishra et al, (1999). Minimum quantity in rainy season may be due to more dilution of water (Patralekh, 1994). It showed positive and significant correlation with TA at the site. Total hardness values of water were significantly $(p<0.01)$ different between months but insignificantly $(\mathrm{p}>0.05)$ different among corresponding months of first and second years (Table 3).

\section{Phosphate}

Minimum phosphate was $0.01 \pm 0.001 \mathrm{mg} / \mathrm{L}$ in October and maximum was $1.23 \pm 0.028 \mathrm{mg} / \mathrm{L}$ in August during first year (Nov 2008 - Oct.2009) (Table 1). During second year (Nov.2009 - Oct.2010), minimum phosphate level was $0.01 \pm 0.001 \mathrm{mg} / \mathrm{L}$ in December and maximum was $1.15 \pm 0.015$ in August (Table 2). It showed positive and significant correlation with water temperature $(\mathrm{r}$ $=0.635, \mathrm{P}<0.05$ ), air temperature but inverse and significant correlation with $\mathrm{TH}(\mathrm{r}=-0.608, \mathrm{P}<0.05)$ (Table 3). Phosphate increases the productivity of ponds.

Table 2. Temperature, water temperature and physico-chemical parameters of water at Site 4 (Betana wetland pond, Belbari, Morang) from November 2009- October 2010 (Mean \pm S.D., N=5).

\begin{tabular}{|c|c|c|c|c|c|c|c|c|c|c|c|c|}
\hline \multirow{2}{*}{\begin{tabular}{|c|}
$\begin{array}{c}\text { Paramet } \\
\text { ers }\end{array}$ \\
$\begin{array}{c}\text { Site - II } \\
\text { Yr. }\end{array}$
\end{tabular}} & \multicolumn{12}{|c|}{ Months } \\
\hline & Nov & Dec & Jan & Feb & Mar & Apr & May & Jun & Jul & Aug & Sep & Oct \\
\hline $\begin{array}{c}\text { Air } \\
\text { Temp. } \\
{ }^{\circ} \mathrm{C}\end{array}$ & $\begin{array}{c}22.03 \\
\pm 0.359\end{array}$ & $\begin{array}{c}20.01 \\
\pm 0.475\end{array}$ & $\begin{array}{l}17.10 \\
\pm .237\end{array}$ & $\begin{array}{c}24.05 \\
\pm 0.691\end{array}$ & $\begin{array}{c}29.1 \\
\pm 0.285\end{array}$ & $\begin{array}{c}27.02 \\
\pm 0.475\end{array}$ & $\begin{array}{c}26.12 \\
\pm 0.229\end{array}$ & $\begin{array}{c}25.05 \\
\pm 0.318\end{array}$ & $\begin{array}{c}29.01 \\
\pm 0.537\end{array}$ & $\begin{array}{c}29.02 \\
\pm 0.742\end{array}$ & $\begin{array}{c}26.15 \\
\pm 0.62 \\
4\end{array}$ & $\begin{array}{c}28.03 \\
\pm 0.35 \\
5\end{array}$ \\
\hline $\begin{array}{c}\text { Water } \\
\text { Temp. } \\
{ }^{\circ} \mathrm{C}\end{array}$ & $\begin{array}{c}21.81 \\
\pm 0.225\end{array}$ & $\begin{array}{c}19.01 \\
\pm 0.317\end{array}$ & $\begin{array}{c}18.04 \\
\pm 0.365\end{array}$ & $\begin{array}{c}21.13 \\
\pm 0.357\end{array}$ & $\begin{array}{c}26.06 \\
\pm 0.523\end{array}$ & $\begin{array}{c}28.05 \\
\pm 0.745\end{array}$ & $\begin{array}{c}25.02 \\
\pm 0.351\end{array}$ & $\begin{array}{c}27.51 \\
\pm 0.432\end{array}$ & $\begin{array}{c}27.03 \\
\pm 0.372\end{array}$ & $\begin{array}{c}28.12 \\
\pm 0.523\end{array}$ & $\begin{array}{c}27.13 \\
\pm 0.34 \\
3\end{array}$ & $\begin{array}{c}25.01 \\
\pm 0.27 \\
3 \\
\end{array}$ \\
\hline pH & $\begin{array}{c}7.12 \\
\pm 0.534\end{array}$ & $\begin{array}{c}7.60 \\
\pm 0.327\end{array}$ & $\begin{array}{c}7.15 \\
\pm 0.365\end{array}$ & $\begin{array}{c}6.61 \\
\pm 0.229\end{array}$ & $\begin{array}{c}7.11 \\
\pm 0.576\end{array}$ & $\begin{array}{c}6.82 \\
\pm 0.317\end{array}$ & $\begin{array}{c}6.95 \\
\pm 0.733\end{array}$ & $\begin{array}{c}7.23 \\
\pm 0.256\end{array}$ & $\begin{array}{c}7.5 \\
\pm 0.075\end{array}$ & $\begin{array}{c}7.01 \\
\pm 0.174\end{array}$ & $\begin{array}{c}7.14 \\
\pm 0.27 \\
1\end{array}$ & $\begin{array}{c}7.11 \\
\pm 0.07 \\
3\end{array}$ \\
\hline $\begin{array}{c}\text { Free } \\
\mathrm{CO}_{2} \\
(\mathrm{mg} / \mathrm{L})\end{array}$ & $\begin{array}{c}17.92 \\
\pm 0.976\end{array}$ & $\begin{array}{c}15.05 \\
\pm 0.735\end{array}$ & $\begin{array}{c}23.75 \\
\pm 0.874\end{array}$ & $\begin{array}{c}23.54 \\
\pm 0.887\end{array}$ & $\begin{array}{c}5.12 \\
\pm 0.325\end{array}$ & $\begin{array}{c}2.24 \\
\pm 0.557\end{array}$ & $\begin{array}{c}3.37 \\
\pm 0.623\end{array}$ & $\begin{array}{c}4.59 \\
\pm 0.076\end{array}$ & $\begin{array}{c}8.1 \\
\pm 0.928\end{array}$ & $\begin{array}{c}13.2 \\
\pm 0.526\end{array}$ & $\begin{array}{c}9.15 \\
\pm 0.75 \\
5 \\
\end{array}$ & $\begin{array}{c}9.46 \\
\pm 0.52 \\
3 \\
\end{array}$ \\
\hline $\begin{array}{c}\text { DO } \\
(\mathrm{mg} / \mathrm{L})\end{array}$ & $\begin{array}{c}5.52 \\
\pm 0.257\end{array}$ & $\begin{array}{c}7.43 \\
\pm 0.067\end{array}$ & $\begin{array}{c}7.99 \\
\pm 0.085\end{array}$ & $\begin{array}{c}5.84 \\
\pm 0.224\end{array}$ & $\begin{array}{c}4.82 \\
\pm 0.068\end{array}$ & $\begin{array}{c}9.74 \\
\pm 0.235\end{array}$ & $\begin{array}{c}4.92 \\
\pm 0.342\end{array}$ & $\begin{array}{c}3.19 \\
\pm 0.254\end{array}$ & $\begin{array}{c}5.47 \\
\pm 0.473\end{array}$ & $\begin{array}{c}5.16 \\
\pm 0.359\end{array}$ & $\begin{array}{c}6.88 \\
\pm 0.46 \\
2\end{array}$ & $\begin{array}{c}5.91 \\
\pm 0.23 \\
5\end{array}$ \\
\hline $\begin{array}{c}\text { BOD } \\
(\mathrm{mg} / \mathrm{L})\end{array}$ & $\begin{array}{c}0.85 \\
\pm 0.055\end{array}$ & $\begin{array}{c}0.26 \\
\pm 0.076\end{array}$ & $\begin{array}{c}3.72 \\
\pm 0.053\end{array}$ & $\begin{array}{c}0.84 \\
\pm 0.026\end{array}$ & $\begin{array}{c}1.35 \\
\pm 0.059\end{array}$ & $\begin{array}{c}6.22 \\
\pm 0.048\end{array}$ & $\begin{array}{c}3.61 \\
\pm 0.107\end{array}$ & $\begin{array}{c}1.82 \\
\pm 0.049\end{array}$ & $\begin{array}{c}1.03 \\
\pm 0.066\end{array}$ & $\begin{array}{c}0.44 \\
\pm 0.073\end{array}$ & $\begin{array}{c}0.71 \\
\pm 0.14 \\
5\end{array}$ & $\begin{array}{c}0.28 \\
\pm 0.04 \\
5\end{array}$ \\
\hline $\begin{array}{c}\text { Chloride } \\
\text { (mg/L) }\end{array}$ & $\begin{array}{c}2.01 \\
\pm 0.037\end{array}$ & $\begin{array}{c}5.02 \\
\pm 0.065\end{array}$ & $\begin{array}{c}7.05 \\
\pm 0.324\end{array}$ & $\begin{array}{c}4.1 \\
\pm 0.352\end{array}$ & $\begin{array}{c}1.01 \\
\pm 0.093\end{array}$ & $\begin{array}{c}2.0 \\
\pm 0.257\end{array}$ & $\begin{array}{c}5.21 \\
\pm 0.135\end{array}$ & $\begin{array}{c}6.02 \\
\pm 0.537\end{array}$ & $\begin{array}{c}5.01 \\
\pm 0.809\end{array}$ & $\begin{array}{c}5.03 \\
\pm 0.372\end{array}$ & $\begin{array}{c}2.02 \\
\pm 0.06 \\
5\end{array}$ & $\begin{array}{c}5.13 \\
\pm 0.08 \\
4\end{array}$ \\
\hline $\begin{array}{c}\text { Total } \\
\text { Alkalin } \\
(\mathrm{mg} / \mathrm{L})\end{array}$ & $\begin{array}{l}117.22 \\
\pm 1.156\end{array}$ & $\begin{array}{l}114.06 \\
\pm 1.654\end{array}$ & $\begin{array}{l}110.05 \\
\pm 1.563\end{array}$ & $\begin{array}{r}197.43 \\
\pm 2.756\end{array}$ & $\begin{array}{l}130.03 \\
\pm 1.187\end{array}$ & $\begin{array}{l}118.81 \\
\pm 1.753\end{array}$ & $\begin{array}{l}132.01 \\
\pm 1.342\end{array}$ & $\begin{array}{c}115.02 \\
\pm 0.953 *\end{array}$ & $\begin{array}{l}126.50 \\
\pm 0.977\end{array}$ & $\begin{array}{l}116.63 \\
\pm 1.785\end{array}$ & $\begin{array}{c}103.23 \\
\pm 0.86 \\
7\end{array}$ & $\begin{array}{c}107.8 \\
1 \\
\pm 0.98 \\
5\end{array}$ \\
\hline $\begin{array}{c}\text { Total } \\
\text { Hardnes } \\
\mathbf{s} \\
(\mathrm{mg} / \mathrm{L}) \\
\end{array}$ & $\begin{array}{c}95.04 \\
\pm 1.325\end{array}$ & $\begin{array}{l}108.95 \\
\pm 1.563\end{array}$ & $\begin{array}{l}114.23 \\
\pm 1.375\end{array}$ & $\begin{array}{r}118.84 \\
\pm 1.623\end{array}$ & $\begin{array}{l}110.88 \\
\pm 0.645\end{array}$ & $\begin{array}{l}110.78 \\
\pm 1.544\end{array}$ & $\begin{array}{c}106.92 \\
\pm 1.563 \\
*\end{array}$ & $\begin{array}{r}104.94 \\
\pm 0.976\end{array}$ & $\begin{array}{l}105.10 \\
\pm 1.067\end{array}$ & $\begin{array}{c}95.04 \\
\pm 0.854\end{array}$ & $\begin{array}{c}89.13 \\
\pm 0.65 \\
9\end{array}$ & $\begin{array}{c}104.9 \\
4 \\
\pm 0.81 \\
6 \\
\end{array}$ \\
\hline $\begin{array}{c}\text { Phospha } \\
\text { te } \\
(\mathrm{mg} / \mathrm{L})\end{array}$ & $\begin{array}{c}0.10 \\
\pm 0.004\end{array}$ & $\begin{array}{c}0.01 \\
\pm 0.001\end{array}$ & $\begin{array}{c}0.080 \\
\pm 0.003\end{array}$ & $\begin{array}{c}0.06 \\
\pm 0.002\end{array}$ & $\begin{array}{c}0.46 \\
\pm 0.007\end{array}$ & $\begin{array}{c}0.46 \\
\pm 0.005\end{array}$ & $\begin{array}{c}0.38 \\
\pm 0.002\end{array}$ & $\begin{array}{c}0.93 \\
\pm 0.021\end{array}$ & $\begin{array}{c}0.18 \\
\pm 0.004\end{array}$ & $\begin{array}{c}1.15 \\
\pm 0.015\end{array}$ & $\begin{array}{c}0.21 \\
\pm 0.00 \\
2\end{array}$ & $\begin{array}{c}0.09 \\
\pm 0.00 \\
1\end{array}$ \\
\hline
\end{tabular}

* Significant differences at $1 \%$ level, $* *$ Significant differences at 5\% level. 
The cycling of phosphorus within lakes and river is dynamic and complex, involving adsorption and precipitation reactions, interchange with sediments and uptake by aquatic biota (Borberg and Persson, 1988). The maximum phosphate was recorded during pre-monsoon and monsoon months whereas minimum values were noticed during post monsoon months.

Table 3. Pearson's correlation coefficient ( $r$ ) for air temperature and physico-chemical parameters of water at Site 4 (average of the corresponding month values) during Nov. 2008 - Oct. 2010; N=12; d. f. $=11$.

\begin{tabular}{|c|c|c|c|c|c|c|c|c|c|c|}
\hline S4-1 & + II & $\begin{array}{l}\text { Water } \\
\text { Temp }\end{array}$ & pH & $\begin{array}{c}\text { Free } \\
\mathrm{CO}_{2}\end{array}$ & $\begin{array}{c}\text { DO } \\
(\mathrm{mg} / \mathrm{L})\end{array}$ & $\begin{array}{c}\text { BOD } \\
(\mathrm{mg} / \mathrm{L})\end{array}$ & $\begin{array}{c}\text { Chlori } \\
\text { de }\end{array}$ & $\begin{array}{c}\text { Total } \\
\text { alk }(\mathbf{m g} / \mathrm{L})\end{array}$ & $\begin{array}{c}\text { Total } \\
\text { hard }(\mathrm{mg} / \mathrm{L})\end{array}$ & $\begin{array}{c}\text { Phosphate } \\
\text { (mg/L) }\end{array}$ \\
\hline & P Cor. & $.947^{*}$ & $-.653^{* *}$ & $-.685^{* *}$ & $-.582^{* *}$ & .106 & .114 & .290 & -.398 & $.549^{*}$ \\
\hline${ }^{\circ} \mathrm{C}$ & Sig.(2-t) & .000 & .021 & .014 & .047 & .742 & .725 & .360 & .200 & .065 \\
\hline Water & P Cor. & 1 & $-.692^{* *}$ & $-.798^{*}$ & $-.596^{* *}$ & .260 & .145 & .082 & $-.623^{* *}$ & $.635^{* *}$ \\
\hline Temp. $^{\circ} \mathrm{C}$ & Sig.(2-t) & & .013 & .002 & .050 & .415 & .653 & .800 & .051 & .026 \\
\hline $\mathrm{H}$ & P Cor. & & 1 & -.185 & .312 & -.513 & .243 & -.143 & .092 & -.520 \\
\hline & Sig.(2-t) & & & .564 & .323 & .088 & .447 & .657 & .777 & .083 \\
\hline Free & P Cor. & & & 1 & .174 & .285 & $-.596^{* *}$ & -.241 & .301 & -.512 \\
\hline$(\mathrm{mg} / \mathrm{L})$ & Sig.(2-t) & & & & .589 & .369 & .041 & .451 & .342 & .089 \\
\hline DO & P Cor. & & & & 1 & .316 & .038 & .008 & .431 & -.569 \\
\hline$(\mathrm{mg} / \mathrm{L})$ & Sig.(2-t) & & & & & .317 & 908 & 981 & .162 & .054 \\
\hline ROD & P Cor. & & & & & 1 & -.225 & -.379 & -.081 & .118 \\
\hline$(\mathrm{mg} / \mathrm{L})$ & $\begin{array}{l}\text { Sig. (2- } \\
\text { t) }\end{array}$ & & & & & & .481 & .224 & .802 & .715 \\
\hline Chloride & P Cor. & & & & & & 1 & .319 & -.238 & .253 \\
\hline (mg/L) & Sig.(2-t) & & & & & & & .312 & .456 & 428 \\
\hline Total & P Cor. & & & & & & & 1 & $.580^{* *}$ & -.052 \\
\hline$y(\mathrm{mg} / \mathrm{L})$ & Sig.(2-t) & & & & & & & & .048 & .872 \\
\hline Total & P Cor. & & & & & & & & 1 & $-.608^{* *}$ \\
\hline$(\mathrm{mg} / \mathrm{L})$ & Sig.(2-t) & & & & & & & & & .036 \\
\hline
\end{tabular}

* Significant at $1 \%$ level $(\mathrm{P}<0.01),{ }^{* *}$ Significant at $5 \%$ level $(\mathrm{P}<0.05)$ and Values not marked denote non-significant correlation.

\section{Conclusions}

All physico-chemical parameters of water in Betana wetland are within permissible limits for the wild as well as culture fish species and other biota. No outbreak of fish diseases occurred during study period. Due to the ecotourism area,human activities may deteriorate the quality of water and species diversity so periodic evaluations of physico-chemical parameters should be done for the maintenance and protection of the environment inBetana wetland. 


\section{References}

Acharjee ML and Barat S. Spatio- temporal Dynamics of physicochemical factors of river Relli in Darjeeling Himalaya, West Bengal, India. NBU J. Anim. Sc., 2011, 5: 24-33.

APHA. "Standard Methods for Examination of Water and Wastewater" (21sted.). Washington, DCUSA. American Public Health Association. 2005.

Aryal S and Lacoul, P. Water quality and diversity of diatoms in Punyamati River, Nepal.Ecoprint, 1996, 3: 45-49.

Bais VS, Agrawal NC and Tazeen, A. Comparative study on seasonal changes in phytoplankton community in the Sagar Lake and Military Engineering Lake (MP) J. Freshwater Biol., 1995, 7: 19-25.

Barat $\mathrm{S}$ and Jha P. Changes in the water quality and total coliform bacterial load in a stretch of river Mahananda at Siliguri city, West Bengal Asian J Microbiol Biotech Env Sc, 2002, 4: 571-575.

Bhowmick BN and Singh AS. Effect of sewage on physico-chemical characteristics and bacterial population in river Ganga at Patna Ind J Ecol, 1985, 12: 141-146.

Boreberg $\mathrm{O}$ and Persson G. Particulate and dissolved phosphorus forms in freshwater: Composition and analysis. Hydrobiol.,1988, $170: 61-90$.

Bose SK and Gorai AC. Seasonal fluctuations of plankton in relation to physico-chemical parameters of a freshwater Tank of Dhanbad, India J Freshwater Biol, 1993, 5: 133-140.

Das, SM. Final report on ecology and fisheries of Kumaon lakes. Report DST, Govt. of India, New Delhi, 1981 pp 130.

Elmore HL and West WF. Effect of water temperature on stream reaeration. J Sanit Eng Div, ASCE, 1961, 87: 59-71.

Ganapati SV. Studies on the chemistry and biology of ponds in the Madras city. Seasonal changes in the physical and chemical conditions of a garden pond containing abundant aquatic vegetation. J Mad Univ, 1941, 13: 55-59.

Ganapati SV. An ecological study of a garden pond containing abundant Zooplankton Proc Indian Acad Sci (B), 1943,17:41-58.

Gautam A. "Ecology and Pollution of Mountain Waters". Ashish Publishing House New Delhi, 1990.

Gupta AK and Srivastava NK. Conservation and management of a tropical wetland around Varunariver. J Freshwater Biol, 1994, 6: 109-13.

Hutchinson AH, Zucas SC and McPhail M. Seasonal variation in the Chemical and physical properties of the waters of the Strait of Georgia in relation to phytoplankton.Trans. Roy Soc Canada, 1992, 3:
177-183.

Jain A, Rai SC, Pal J and Sharma E. Hydrology and nutrient dynamics of a Sacred Lake in Sikkim Himalaya. Hydrobiol, 1999, 416: 13-22.

Jana BB. State of the art of lakes in India; An overview. Arch Hydrobiol Suppl Vol, (Monogr Stud),1998, 121: 1- 89

Jhingran VG. "Fish and Fisheries of India" 3rd edition. Hindustan Publ New Delhi,1991.

Jindal R and Kumar R. Limnology of a freshwater pond of Nalagarh (Himachal Pradesh India). 1. Physicochemical complex. In: "Advances in Limnology" (HR Singh, Ed) Narendra Publishing House, Delhi, 1993, pp. 107-12.

Klein L. Aspect of river pollution butter worth scientific pollution, London, 1957.

Latifa GA and Acharya GS. Evaluation of physicochemical parameters in freshwater pond. Ecoprint, 2001, 8: 111-12.

Lohman K Jones MFK, Swar DG, Pamperl MA and Brazos BJ. Pre and post monsoon limnological characteristics of lakes in the Pokhara and Kathmandu Valleys, Nepal. Verh Internat Verein, Limnol, 1988, 23: 558-65.

McEachern P. Limnology and the natural wetlands survey. In: "Safeguarding Wetlands in Nepal ". (B. Bhandari, TB Shrestha and P McEachern Eds.), 1994, pp. 89-103. IUCN, Nepal.

Mishra AP, Bora BK and Sharma M. Investigations on the seasonal variation of certain Physico-chemical parameters of a Beel, Assam, India. J Freshwater Biol, 1998, 10: 83-7.

Mishra AP, Bora BK and Sharma M. Limnological investigation of a freshwater tributary Assam, India. J Freshwater Biol, 1999, 11: 1-5.

Moitra SK and Bhattacharya BK. Some hydrobiological factors affecting plankton production in fish pond at Kalyani W.B. India Ichthyol, 1965,4: 8-12.

Niroula B, Singh KLB, Thapa GB and Pal J. Seasonal Variations inPhysico-Chemical Properties and Biodiversity in Betana Pond, Eastern Nepal .Our Natr, 2010, 8:212-8.

Onada OA, Akinwole AO and Ajani EK. Study of interrelationship among water quality parameters in earthen pond and concrete tank. Department of Aquaculture and Fisheries Management, University of Ibadan, Nigeria. Peer J Pre Print, 2015, Retrieved http://dx.doi.org/10.7287/peerj.preprints.845v1.

Ormerod SJ, Buckton ST, Brewin PA, Jenkins A, Johnson, RC Juttner, U and Suren A. Biodiversity, chemistry and structure in streams of the Nepalese Himalaya. Proc Inter Confer Ecohydrol High Mount 
Kathmandu, Nepal, 1996,pp. 197-200.

Pahwa DV and Mehrotra SN. Observations on fluctuations in abundance of plankton in relation to certain hydrobiological conditions of river Ganga Proc Natl Acad Sci, India, 1966, 36 B 2: 57-189.

Palharya JP and Malviya S. Pollution of the Narmada at Hoshangabad in Madhya Pradesh and suggest measure for control. In: "Ecology and Pollution of Indian Rivers"(RK Trivedy, Ed), 1988, pp. 55-86. Ashish Publishing House, New Delhi.

Palui D, Shrivastava VK and Jha BC. Eutrophication in Kaithkhola Ox-Bow lake, North Bihar. J Inland Fish Soc India., 2003, 35: 19-24.

Pandey KK and Lal MS. Limnological studies of Garhwal Himalayan hill stream Khandagad: Seasonal fluctuation in abiotic profile. J Freshwater Biol, 1995, 7: 7-11.

Parisara N. Water quality evaluation of Konandur pond, Thirthalli, Karnataka, India. Ind J Appl Biol, 2015, 6:200-4.

Patralekh LN. Comparative account of physico-chemical properties of three fresh water ecosystems. J Freshwater Biol, 1994, 6: 115-9.

Rawat MS, Juyal CP and Sharma RC. Morphometry and physico-chemical profile of high altitude lake Deoria Tal of Garwal Himalaya. J Freshwater Biol, 1995, 7: 1-6.

Ray P, Singh SB and Sehgal KL. A study on some aspects of the river Ganga and Jamuna at Allahabad (UP) in 1958-59. Proc NatAcad Sci, 1966, 36B: 235-72.

Roy H. Plankton ecology of river Hooghly (West Bengal). Ecol, 1955, 36: 169-744.

Sakhare VB and Joshi PK. Present status of reservoir fisheries in Maharastra. Fish Chimes, 2004, 24: 5660.

Samal NR and Majumdar A. Management of Lake Ecosystem. The Ekol, 2005, 3: 123-30.

Sharma BS and Agarwal A. Assessment of water quality of river Yamuna at Agra. Polln Res, 1999, 18: 10910.

Sharma UP. Ecology of the Koshiriver in Nepal-India (North Bihar): A typical river ecosystem. In: Environment and Biodiversity: In the Context of South Asia (PK Jha, GPS Ghimire, SB Karmacharya, SR Baral and P Lacaul, Eds),1996, pp.92-99. Ecological Society (ECOS), Kathmandu, Nepal.

Singh HP. Distribution and seasonal fluctuation of certain physico-chemical features in the Brahmaputra River. J Assam Sci Soc, 1990, 32: 64-9.

Singh J, Agrawal DK and Panwar S. Seasonal variations in different physicochemical Characteristics of Yamuna river water quality in proposed Lakhwar hydropower project influence area. Int J Appl Env Sc, 2008, 3: 107-17.

Singh M. Impact of human activities on the physicochemical conditions of two fish ponds at Patna, India. J Freshwater Biol, 1995, 7: 13-7.

Swarup K and Singh SR. Limnological studies on Surahalake (Ballia). J Inland Fish Soc India, 1979, 11:22-3.

Thapa Chhetry D and Pal J. Physico-chemical Parameters of Koshi River at Kushaha Area of Koshi Tappu Wildlife Reserve. Our Nature, 2011, 6: 16-25.

Thapa, GB and Pal J. Studies on some physicochemical parameters of Baidya and Itahari Municipality fish ponds, Nepal. NBU J Anim Sc, 2012, 6: 26-39.

Thapa GB and Pal J. Evaluation of physico-chemical characters of Singhia and Budhi rivers in Sunsari and Morang Industrial corridor, Nepal. Int $\mathrm{J}$ Adv. Res Biol Sci, 2014, 1: 104-12.

Thresh JC, Beale JF and Suckling EV. The examination of water and water supplies (EW Taylor, Ed), London J and A Churchill Ltd, 1949.

Trivedy RK and Goel PK. Chemical and Biological Methods for Water Pollution Studies. Environmental Publications, Karad, Maharashtra, India, 1986.

Wright JF, Moss D, Armitage PD and Furse MT. A preliminary classification of running water sites in Great Britain based on macro invertebrate species and the prediction of community type environmental data. Freshwater Biol Assoc, 1985, 53: 80- 93 .

Yousuf AR and Bhat FA. Limnological features of River Jhelum and its important tributaries in Kashmir Himalaya with a note on fish fauna. J Himalayan Ecol Sustain Dev, 2006, 1:37-50. 